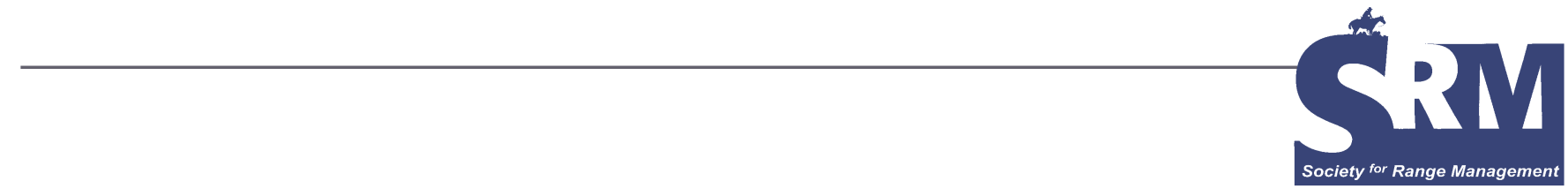

\title{
National Security and
} Rangelands

\section{Depletion of fossil fuels and global warming could drastically reduce world food production. Conserving and improving rangelands is important, because they likely will play an increased role in meeting world food needs.}

\section{By Jerry L. Holechek}

I $\mathrm{n}$ recent years, the term "national security" has been increasingly used by US politicians to justify major military and economic spending programs by the federal government. These national security spending programs initially centered on protecting US citizens from terrorist attacks following the September 11, 2001 destruction of the New York World Trade Center buildings. However, the term "national security" is becoming more inclusive, taking into account energy, climate, transportation, the economy, and food production and distribution. Both energy (peak oil) and climate (global warming) concerns are receiving more attention by the politicians and news media but they remain greatly overshadowed by the "War on Terror."

Critics of the "War on Terror" tend to focus on the high natural resource consumption (particularly oil and natural gas) levels of the United States compared to other countries. ${ }^{1-3}$ Many see the major problem as the heavy US dependence on oil imports from certain foreign countries that are not dependable friends or politically stable.

Although various books and articles have been written that make the case for less reliance on imported resources, there has been little focus, discussion, or debate on this matter by the politicians and news media. In reality, the accelerated trend towards globalization since 1990 has greatly increased US dependence on imported resources and goods. ${ }^{4,5}$ It is amazing to me that the relevance of rangelands in meeting the national security needs of the United States is seldom mentioned by the politicians or news media, even though rangelands comprise half the total land area of the United States.

The American Farmland Trust ${ }^{6}$ summarizes justification to conserve and protect agricultural lands, including rangelands. In general, they make the case that saving agricultural lands from development is advantageous, both economically and environmentally, but they do not imply or directly state this is essential for national security. Primary economic reasons given to save agricultural lands include importance of agricultural products in international trade and employment of nearly 23 million people in the nation's food production system. Environmental reasons for saving agricultural lands include their importance for wildlife habitat, clean air, water, flood control, ground water recharge, and carbon sequestration. Other socially related justifications are preservation of cultural heritage, scenic views, open space, and community uniqueness. Although these reasons are all compelling, they thus far have not led to any federal initiatives to slow the rate of development of agricultural lands. From 1992-2003, the rate of development of agricultural lands has actually increased by $50 \%$ compared to the previous decade. ${ }^{6}$ Since 1994 , lots of 10 to 22 acres have accounted for $55 \%$ of the growth in housing areas.

Although the trend in agricultural land loss might seem alarming, there is a counterview that the United States still has a vast abundance of agricultural land, and conversion 
is small relative to the total base. ${ }^{7}$ About $5.5 \%$ of the land in the United States is considered to be developed. Development of agricultural lands often results in accelerated economic growth in local communities with more and higher paying jobs than with agriculture alone. Restrictions on development of agricultural lands at the federal, state, and/or county level interfere with free market forces and compromise private property rights. In states such as Oregon and California, with intensive land use restrictions, home availability and prices are bid up due to the lack of land for subdivisions.

After reading a number of articles and books on problems relating to urban sprawl, food production, fossil fuel depletion, and global warming, I have become convinced there are more compelling reasons to conserve agricultural lands from development beyond those I have previously summarized. These reasons are related to transportation, food, and climate security. Of these, I believe food security could be the most important. From here I will make the case that both conserving and improving rangelands will be critical in security needs, emphasizing food production.

\section{American Agriculture-A Success Story?}

The United States' abundance of cheap food is considered to be one of the country's greatest achievements. ${ }^{8,9}$ While people in most parts of the world spend about $40 \%$ of their disposable income on food, in the United States we spend only $10 \%$. Americans eat better and at the same time spend a lower percentage of their income on food than any other country. Today, less than $1 \%$ of the work force in the United States engages in farming and ranching. Some examples of changes in agricultural production from the 1950s to the present include the following: annual egg production has jumped from 183 to 243 eggs per laying chicken, milk output has increased from 5,400 to 12,100 pounds per cow, wheat output has increased from 17 to 35 bushels per acre, and corn output has jumped from 39 to 102 bushels per acre. ${ }^{8}$ During this same period, farm output per hour of labor has increased a phenomenal 700\%. Since World War II, agricultural exports from the United States have played a critical role in meeting the food needs of several developing countries. Agricultural products have been primary exports from the United States during several periods since World War II. In spite of its successes, the capability of US agriculture to meet future food needs, both at home and abroad, is being questioned. ${ }^{10-13} \mathrm{~A}$ number of problems confront American agriculture, including soil erosion, restricted water supplies, water pollution, atmospheric pollution, global warming, urban sprawl, rapidly rising fossil fuel costs, and plant biological yield limits. ${ }^{10,11,13}$ Although the United States has long been the world's leading exporter of agricultural products, it has also recently become the leading importer. In 2006, the United States became a net importer of agricultural products for the first time, after nearly 50 years of being a net exporter of agricultural products.
Since 1960, the "green revolution" has been the primary factor explaining the tremendous increase in world food production. ${ }^{10,13,14}$ Its key features are genetic selection of highly adapted plant species that are responsive to large inputs of inorganic fertilizer, pesticides, and irrigation water. ${ }^{10,14}$ Three- to five-fold increases in yields over traditional varieties were possible with appropriate water, fertilizer, and pesticide inputs. Faster growth of certain green revolution plants has permitted multiple cropping on the same amount of land.

The primary problems now emerging with the green revolution are depletion of the world's supply of fossil fuels and ground water for irrigation. ${ }^{10-12}$

\section{Human Population, Food, and Energy}

Since 1950, to the present, the world human population has increased $250 \%$, from 2.6 to 6.5 billion people. This increase has been made possible by a $300 \%$ grain yield increase from the green revolution. ${ }^{10}$ The world human population is projected to grow from 6.6 to 9 billion people by 2042 according to the US Census Bureau. However, some experts are now questioning whether the world can support the present human population, let alone another 2 to 3 billion people. ${ }^{2,11,15}$ Their primary concern centers around the heavy dependency of modern agriculture on fossil fuels. A secondary concern is the impact of climate change on food production. Between 1945 and 1994, energy inputs to agriculture have shown a 4-fold increase, but crop yields have shown only a 3 -fold increase. ${ }^{16}$ Since 1994, energy input has continued to increase without a corresponding increase to crop yield. ${ }^{10}$ American agriculture's energy use is partitioned as follows: $31 \%$ for fertilizer manufacture, $19 \%$ for operating field machinery, $16 \%$ for transportation, $13 \%$ for irrigation, $5 \%$ for pesticide production, and $16 \%$ other. ${ }^{10}$ Energy costs for packaging, refrigeration, transportation to retail outlets, and household cooking are not included in these figures. An increasing percentage of the food consumed by Americans comes from other countries. ${ }^{10}$ Based on USDA data, an estimated $39 \%$ of fruits, $12 \%$ of vegetables, and $78 \%$ of fish are imported. Currently, the average food item consumed in the United States travels about 1,500 miles, compared to 1,250 miles 20 years ago. ${ }^{17}$ For every calorie used in actual food production, up to 5 more are used for processing, storage, and transport. Every aspect of food production, processing, distribution, and consumption depends on oil and natural gas supplies. Without question, food security in America relies heavily on the steady availability of cheap oil and natural gas. Because the United States is so heavily dependent on oil and natural gas imports, there is growing concern this could be our Achilles heel. ${ }^{18-20}$

\section{Growing Concern Over Peak Oil}

"Peak oil" is a term commonly used in reference to global oil production reaching a maximum and then declining due 
to depletion of finite reserves under stable or increasing demand. ${ }^{10,18,20}$ Considerable controversy has surrounded exactly when this might occur, although it is well-accepted that it will occur because oil is a finite, nonrenewable natural resource. ${ }^{18,20}$ In February 2007, the US General Accounting Office (GAO) concluded that peak oil will likely occur between now and 2040, depending on a variety of factors. The most important of these factors are great uncertainties about world oil reserves, technological capability to extract oil from the ground, capability to substitute other fossil fuel sources (coal, oil shale, oil sands) for oil, and development of alternative nonfossil fuel energy sources (wind, hydrogen, ethanol, nuclear, biomass). Other concerns relating to the US oil adequacy for the United States are potential disruptions in primary oil producing regions from terrorists, political turmoil, hurricanes, and uncertainty about future world oil demand. ${ }^{20}$

Even though the United States is currently the third largest oil-producing nation, US oil production peaked in 1970 and has been declining ever since. ${ }^{20}$ Therefore, US reliance on imported oil has steadily increased since 1970. In 2005, the United States imported about $66 \%$ of its oil and petroleum products (20). Although new energy sources are becoming available, oil demand in the United States is continuing to grow at nearly $1.5 \%$ per year. At the same time, oil demand in other parts of the world, particularly China and India, is expanding. The 2007 GAO report discusses problems with various energy alternatives, such as ethanol, hydrogen fuel cells, and hybrid vehicles. It concludes these energy alternatives have potential to reduce US reliance on imported oil but several years of development will be needed before their impact is significant. If peak oil should occur within the next 5 to 10 years, the consequences would be severe globally, but most dire for the United States because it is the world's largest oil consumer and most dependent on oil for transportation. ${ }^{20}$ Whereas the 2007 GAO report emphasizes US transportation vulnerability to peak oil, other reports show greater concern over food security. ${ }^{2,10}$

\section{Global Warming and Peak Oil}

Together peak oil and global warming are two of the biggest challenges confronting humanity as we move into the 21st century. The fourth assessment report (April 2007) of the Intergovernmental Panel on Climate Change (IPCC) leaves little doubt that global warming is occurring and is caused primarily from carbon dioxide emissions from human fossil fuel usage. The IPCC directly states the primary solution to global warming is to curb fossil fuel use and develop alternative energy sources. Basically the same set of energy solutions associated with peak oil apply to reducing global warming. However, the problems that global warming poses for world food security are different than those from oil depletion. It is probable global warming will adversely impact agriculture by making regional temperature and precipitation regimes annually more variable, with some areas becoming drier and others wetter. Intense droughts followed by intense flooding will likely occur much more frequently. Crop yield losses from insects and diseases will probably intensify. On a short-term basis (next 10 to 20 years), increases in atmospheric carbon dioxide levels from global warming might increase US crop yields. However, on a longer-term basis, increased aridity, coupled with erratic precipitation amounts and intensity, will likely reduce food production, particularly grain yields in the Great Plains.

Although I consider global warming a serious long-term food production threat in the United States, I believe peak oil to be the bigger short-term problem. I base this view on the 2007 GAO report that peak oil is impending and strongly urge the US federal government to develop a well-defined strategy to deal with its consequences. However, the news media and politicians have been placing more emphasis on global warming. Nevertheless, both peak oil and global warming will likely force major changes in both transportation and agriculture in the United States and world. Globalization vs localization is at the center of the debate over changes that will occur.

\section{Globalization versus Localization}

Globalization refers to the economic, social, and cultural integration of the world's various countries. ${ }^{2-4}$ Basically, globalization centers around unrestricted free trade among countries. International trade, free movement of capital and labor, and integration of financial markets are key features of globalization. Globalization depends heavily on removal of trade barriers (tariffs and quotas), international cooperation, and an abundant supply of cheap energy. Since World War II, the United States has been the world's largest promoter of globalization. In large part, this is because the United States is the world's largest economy. US multinational corporations, such as Wal-Mart and McDonald's, have greatly benefited by increased opportunities to sell their products in other countries. They also benefit from reduced labor costs, taxes, and environmental regulations that occur when they are able to relocate part or all of their business in countries such as China or India. Conversely, globalization has given American consumers a great deal of access to a wide variety of low-priced goods and foods produced in China, Japan, Mexico, Korea, India, and various other countries. Without question, living costs in America would be significantly higher (by some estimates, 20\% to $40 \%$ higher) without the globalization that has occurred over the last 15 years. George H. W. Bush, Bill Clinton, and George W. Bush have all been strong promoters of globalization and have accelerated its progress through various trade agreements.

In direct opposition to globalization, localization is a new term and movement that involves rearranging city and county level economies so they are self sufficient rather than dependent on high levels of imported food and 
energy. ${ }^{2,10}$ Key features of localization are transition to local, renewable energy sources, and food production from urban gardens and local agricultural lands. Basically, the localization movement is a counter response to peak oil, oriented toward natural resource and environmental sustainability. It emphasizes self sufficiency and renewability.

Globalization in moderation-involving some exchange of people, capital, goods, services, culture, and ideas among nations - is considered a positive thing by nearly all economists. ${ }^{8,9}$ The early free-market economist, Adam Smith, made the case that free trade improves human living conditions by lowering prices, increasing availability of goods and services, and raising employment. However, when free trade does not involve balanced trade, it can become socially and economically destructive. ${ }^{3-5}$ Since 1972 , when the US dollar became the world's reserve currency, the United States has increasingly engaged in unbalanced trade with increasing annual trade deficit now over 800 billion dollars. ${ }^{4,5}$ Once peak oil occurs, it will no longer be rational for countries such as China and India to send goods to the United States without receiving real goods, food, natural resources, or services in return. It seems most unlikely that the oil exporting countries will indefinitely accept mere paper dollars (if not fully backed by gold, goods, or food) for their commodity. Ultimately, I believe the United States could have two choices to meet its fossil fuel needs. One option will be to drastically change lifestyles of the people so they must depend much more on what the United States can produce internally, whereas the other will be for the United States to sustain its current lifestyle through projection of military force. I am hopeful that in the end, the United States will solve its energy problem through conservation, innovation, and development of its own resources. Under this choice, rangelands will play a critical role in national security.

\section{Current Status of Range Livestock Production}

Since the early 1980s, the role of range livestock production in meeting US food needs has been progressively diminished. In the mid-1980s, huge grain surpluses, coupled with historically low real (inflation adjusted) oil prices, made it feasible to produce high quantities of cheap meat using grains rather than range, pasture, and crop roughages as primary livestock feeds. ${ }^{21}$ At the same time, world beef production started expanding through conversion of tropical rain forests into pastureland in several South American countries. Globalization, coupled with cheap oil, made it feasible for the United States to import high quantities of low grade beef. Various subsidies, low labor costs, cheap transportation, and lack of environmental regulation gave beef production advantages to other foreign countries. The low meat prices and capability to import high food quantities since the mid-1980s have caused environmental groups and many politicians to view western rangelands as a nonessential, disposable resource that can be converted into nature reserves, wildlife sanctuaries, industrial parks, airports, recreational resorts, ski areas, golf courses, ranchettes, housing projects, etc., without adverse economic consequences. Ranching has come to be viewed much more as a cultural heritage and recreational activity than as an essential industry.

There is ample scientific information showing range livestock production to be the most environmentally benign and energy efficient of all land-based food production systems..$^{22,23}$ Problems of overgrazing have been greatly reduced across upland and riparian landscapes of the western United States based on my own observations. However, active investments (fire, herbicides, mechanical treatment, seeding) to improve western rangelands for food, water, fiber, and energy production have been meager. This neglect has caused a gradual decline in the forage-producing capability on many US rangelands. Across the western United States, brush and noxious plant problems are widespread. Although current data are lacking, in 1992 serious problems occurred on about $60 \%$ of our rangelands with minor problems on another $27 \% .^{24}$

If peak oil is near and major breakthroughs do not soon occur in development of alternative, clean, cheap energy sources, range livestock production could again play a vital role in supplying the United States with meat. Under conditions of peak oil without cheap alternative energy sources, food prices could rise sharply, particularly for meat. It might no longer be feasible to feed large quantities of grains to cattle because of their low conversion efficiency (about 10\%) into meat. Rather, most of the grain production would be directly consumed by humans or used for the ethanol production. Depending on severity of the oil shortage, limited amounts of grain will be fed to pigs and chickens because they more efficiently convert grain to meat than cattle. However, it is probable those meats will become very expensive and exceed grass-fed beef in per pound cost to consumers.

It is possible that both farming and ranching profits could increase as they did in the oil shock of the 1970s. There would likely be another major push to increase meat production from public and private rangelands. The role of large scale federal government assistance and subsidization of range improvements may again be debated by US Congress.

\section{Federal Funding for Range Improvements}

Under the 2002 Farm Bill, the federal government spends no more than 3 billion dollars annually on active improvements on private and public rangelands. This includes 1 billion dollars for the US Department of Agriculture's Environmental Quality Incentives Program (EQIP) for privately owned rangelands, administered by the Natural Resources Conservation Service. Total federal money spent on management of public and private rangelands is near 4 billion dollars. Remember, the federal government's 2007 budget is about 3 trillion dollars ( 1 trillion is 1,000 billion). 
Expenditure for the Iraq War will be near 100 billion dollars in 2007 and by year's end, the total 5-year cost will be 500 billion. From this, it is apparent annual federal funding for management and enhancement of the nation's rangelands is extremely low (about one tenth of one percent of the federal budget). On the other hand, rangelands comprise half of the nation's land area. If the money spent so far on the Iraq War would have been spent on improving the nation's rangelands, it would have amounted to five hundred dollars per acre.

\section{A Viewpoint Regarding the Future}

In my opinion, it would be wise for the United States to increase its investment in conservation, enhancement, and development of its rangeland resources as a rational hedge against the impending problems from peak oil and global warming. As a realist, I understand that under present conditions, capability to project military force is essential for the United States to ensure it obtains the vital natural resource imports (oil and natural gas) on which it is now so dependent. However, it seems both rational and prudent to minimize this dependency as quickly and as reasonably as possible. I recognize this will require a wide variety of strategies involving energy conservation, lifestyle changes, development of alternative energy sources, modifying transportation systems, and modifying food production systems. It seems to me that conservation and improvement of rangelands should be part of this strategy. How rangelands are used will undoubtedly affect future transportation and food security of the United States. For nearly 25 years, both low ranching profitability and lack of federal funding have caused a slow decline in forage productivity on many US rangelands, due to brush and noxious plant invasion. As the stands of brush and trees thicken and grow taller, the cost and difficulty of correcting the problem increases (Fig. 1). Eventually many of these lands become so dominated by

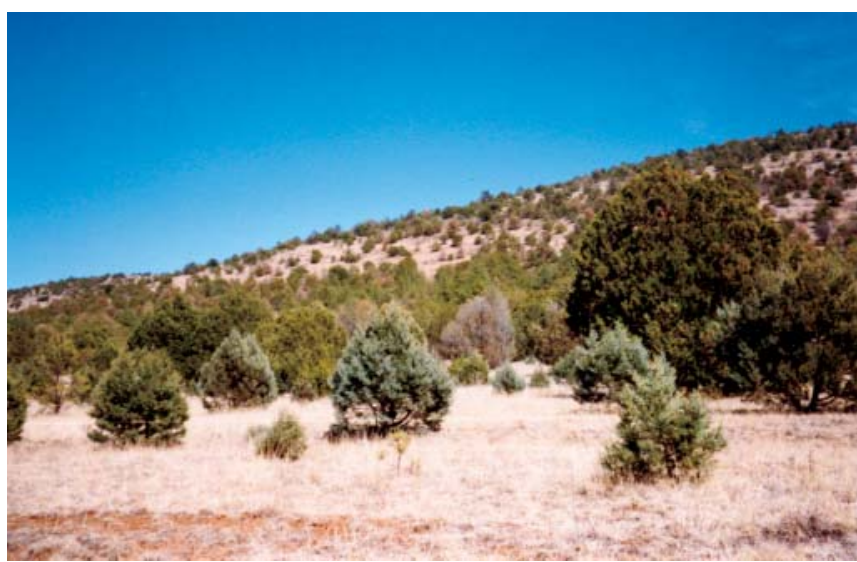

Figure 1. The value of this rangeland in western New Mexico for livestock, water, and wildlife is being gradually reduced by pinyon-juniper invasion. This problem occurs over large areas of New Mexico and other western states.

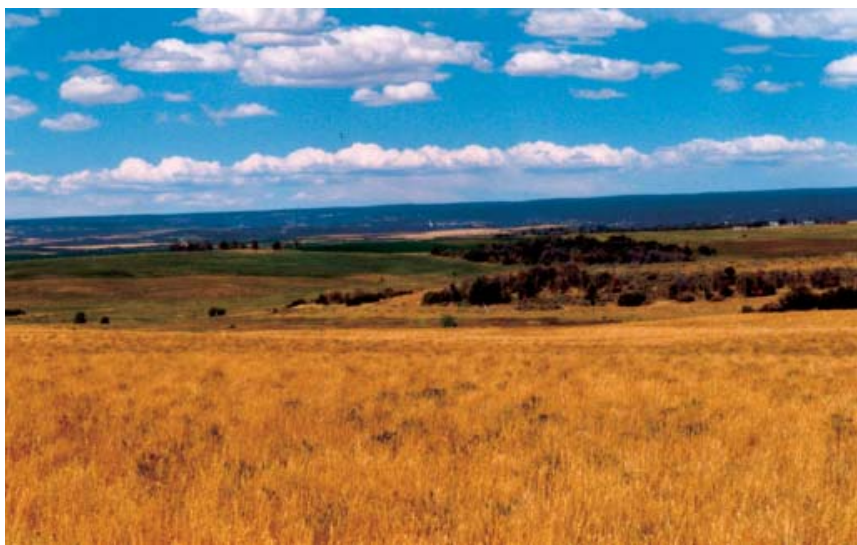

Figure 2. Grazing, farming, wildlife, and watershed values have been nicely integrated at the landscape level on this agricultural area in western Colorado.

woody vegetation they lose most or all of their value from forage, watershed, and wildlife standpoints.

A well-thought-out and -implemented strategy for improving the nation's rangelands, focusing on brush management, could accomplish several other objectives in addition to improving food security. Increased investment in our rangelands would reduce unwanted wildfire problems, increase employment, enhance watershed health, increase economic growth, enhance climatic stability, and improve wildlife habitat. The type of strategy I have in mind would emphasize self-sufficient local economies, keeping ranchers on the land, improve food security, and increase employment opportunities in ranching areas. It would emphasize integrating agriculture and nature (Fig. 2). A prosperous ranching economy would greatly curb conversion of rangelands into other uses. Food, energy, water, and wildlife would the primary products from this strategy.

On private lands, I suggest a program of low-interest government loans to ranchers for range enhancement (primarily brush control) with payback tied to livestock prices, agreements not to subdivide the ranch, and provision of ecosystem services. We now have sufficient research to apply brush and noxious plant control in ways that improve wildlife habitat while increasing forage for livestock (Figs. 3 and 4). Basically, the present EQIP program administered by the USDA-NRCS could be expanded and modified to meet this need.

On federal rangelands, uncertainty of grazing privileges, environmental regulations, and cost all necessitate that range improvement programs be government funded. It seems to me that the federal government that owns and controls these lands should also be responsible for maintaining and increasing their productivity for various uses (water, forage, wildlife, recreation, timber, etc.). Although I have serious concerns about ever-increasing federal debt levels, it seems that severe underinvestment is occurring on the nation's federal rangelands. 


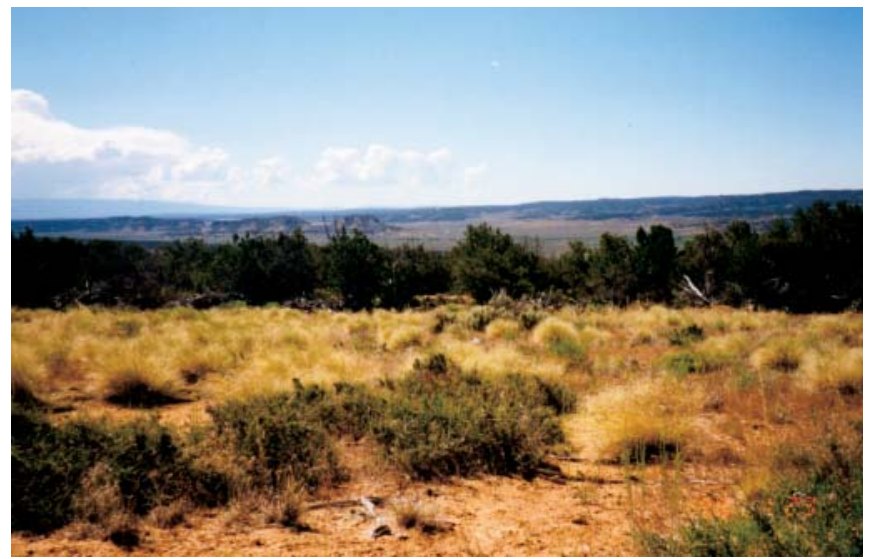

Figure 3. This pinyon-juniper control project in north-central New Mexico greatly improved forage for livestock, mule deer, and elk, as well as improving watershed and esthetic values.

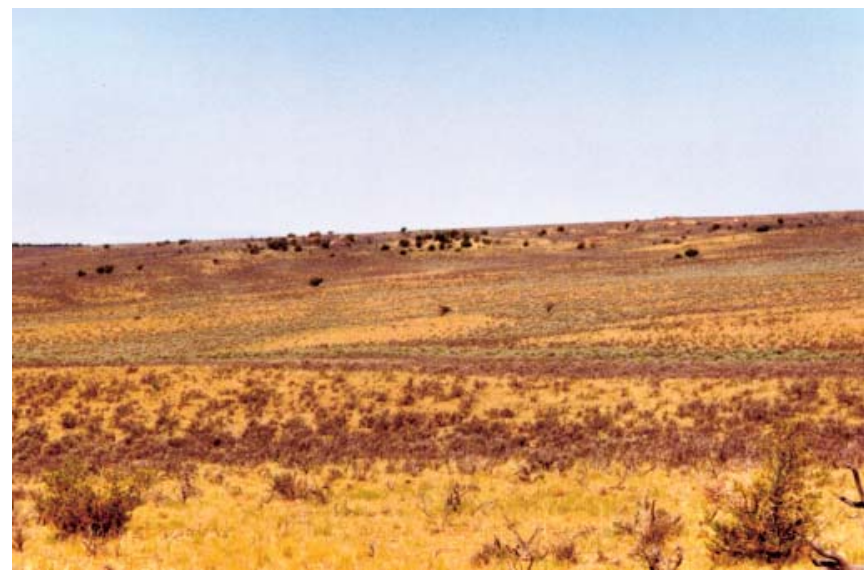

Figure 4. Big sagebrush was controlled leaving patches for wildlife and esthetic purposes on this rangeland in northwestern New Mexico.

I believe that a national land use committee is needed to assess the magnitude and implications of present land use patterns across the United States in terms of transportation, food, climatic, and economic security. The past and present trend for America to sprawl, or build out, rather than build up, does not seem rational and sustainable under conditions of peak oil and global warming.

\section{References}

1. Klare, M. T. 2004. Blood and oil. New York, NY: Henry Holt and Company. 277 p.

2. Kunstler, J. H. 2005. The long emergency. New York, NY: Grove Press. 525 p.

3. Faux, J. 2006. The global class war. Hoboken, NJ: John Wiley \& Sons, Inc. 324 p.

4. Duncan, R. 2005. The dollar crisis: Causes, consequences, cures. Hoboken, NH: John Wiley \& Sons. 292 p.

5. Prestowitz, C. 2005. Three billion new capitalists. New York, NY: Basic Books. 321 p.

6. American Farmland Trust. 2003. Why save farmland? Farmland Information Center fact sheet. Washington, DC: National Office. 3 p.
7. Staley, S. 2000. The "vanishing farmland" myth and the smart growth agenda. Reason Public Policy Institute. Policy Brief No. 12.17 p.

8. Schiller, R. R. 1991. The economy today. 5th ed. New York, NY: McGraw-Hill. 712 p.

9. Knutson, R. D., J. B. Penn, and B. L. Flinchbaugh. 1998. Agricultural and food policy. 4th ed. Upper Saddle River, NJ: Prentice Hall. 521 p.

10. Pfeiffer, D. A. 2006. Eating fossil fuels. Gabisola Island, British Columbia, Canada: New Society Publishers. 125 p.

11. Brown, L. R. 1998. Struggling to raise cropland productivity. In State of the World. World Watch Institute. New York, NY: W. W. Norton \& Co. p. 79-96.

12. Pyle, G. 2005. Raising less corn, more hell. Cambridge, MA: Public Affairs/Perous Books Group. 229 p.

13. Holechex, J. L., R. A. Cole, J. T. Fisher, and R. Valdez. 2003. Natural resources: Ecology, economics, and policy. 2nd ed. Upper Saddle River, NJ: Prentice-Hall. 761 p.

14. Chrispeels, M. J., and D. Sadava. 1977. Food, plants, and people. San Francisco, CA: W. H. Freeman. 238 p.

15. Pimentel, D., R. Harmon, M. Pacenza, J. Pecarsky, and M. Pimentel. 1994. Natural resources and an optimum human population. Population and Environment 15:347-369.

16. Pimentel, D., and M. Giampietro. 1994. Food, land, population and the U.S. economy. Cornell, NY: Carrying Capacity Network. 55 p.

17. Pirog, R., T. Van Pelt, K. Bushayz and B. Cook. 2001. Food, fuel and freeways: A Iowa perspective on how far food travels, fuel usage, and greenhouse gas emissions. Leopold Center for Sustainable Agriculture. Ames, IA: University of Iowa. 5 p.

18. Simmons, M. R. 2005. Twilight in the desert. New York, NY: John Wiley and Sons. 422 p.

19. Tertzakian, P. 2006. A thousand barrels a second. New York, NY: McGraw-Hill. 272 p.

20. United States Government Accounting Office (GAO). 2007. Crude oil: Uncertainity about future oil supply makes it important to develop a strategy for addressing a peak and decline in oil production. GAO Dept. 07-283. Washington, DC: Government Accountability Office. 76 p.

21. Holechek, J. L., J. Hawkes, and T. D. Darden. 1994. Macro economics and cattle ranching. Rangelands 16: 118-123.

22. Соок, C. W. 1976. Cultural energy expended in range meat and fiber production. Journal of Range Management 29:268-271.

23. Соок, C. W. 1979. Meat production potential on rangelands. Journal of Soil and Water Conservation. 34:168-171.

24. United States Department of Agriculture-Natural Resources Conservation Service. 1992. Natural Resources Inventory. Washington, DC: Government Printing Office. $188 \mathrm{p}$.

Author is Professor of Range Science, Department of Animal and Range Sciences, New Mexico State University, Las Cruces, NM 88003, holechek@nmsu.edu. This paper was supported by the New Mexico Agricultural Experiment Station and was part of project 1-5-27410. 